\title{
MUNICIPAL WASTE MANAGEMENT IN ROMANIA IN THE CONTEXT OF THE EU. A STAKEHOLDERS' PERSPECTIVE
}

\author{
Carmen NASTASE ${ }^{\circledR}$, Carmen Emilia CHAȘOVSCHI ${ }^{(D)}$, \\ Mihaela STATE ${ }^{\text {D }}$, Adrian-Liviu SCUTARIU \\ Faculty of Economics and Public Administration, "Ştefan cel Mare" \\ University of Suceava, Suceava, Romania
}

Received 09 July 2018; accepted 17 February 2019

\begin{abstract}
The European waste policy is focused on reducing the negative impact of waste, eliminating the unhealthy use of resources, and on better waste management. The aim of this paper is to analyse Romanias waste management practices in the EU context. The research methodology is based on a quantitative and qualitative analysis. The descriptive data analysis reveals significant differences among $\mathrm{EU}$ countries in terms of the municipal waste generated and the recycling rate. The municipal waste generated registers decrease, whereas there are significant increases in terms of the recycling rates in the EU countries. The qualitative research is based on the analysis of structured interviews among stakeholders, relevant for the waste management in Romania. The information obtained based on interviews was processed using NVivo and the main findings are focused on recommendations for improving the waste management system. We have identified a lack of adequate public support in the waste field due to insufficient awareness programs, lack of operator's obligation for separate waste sanitation, people's discouragement to separate their household waste, and lack of bins to separate collection. The correction of identified weaknesses could lead to an improved waste management system, feasible only through an active involvement of stakeholders.
\end{abstract}

Keywords: community-based initiative, sustainable economy, municipal waste management, recycle, household consumption, policy recommendations, stakeholders' perception.

JEL Classification: Q53, Q01, Q28, Q58.

\section{Introduction}

In the last decades, the economic growth of the European Union countries has generated an increase of life standards and consumption. The production and income have surged and, due to a moderate and low inflation rate, the average purchasing power of people has also risen, especially in the Eastern and Central Europe. This is also the case of Romania (Căilean Gavrilescu \& Teodosiu, 2016). This lead to an increased volume of generated waste from

\footnotetext{
${ }^{*}$ Corresponding author. E-mail: livius@seap.usv.ro
} 
producing goods and as well from consumption. The increasing volume of waste has brought the need to find solutions, which are included in what we call waste management. The idea is to use this waste in certain ways, to avoid the landfill and negative effects of environment as much as possible. The European Union is highly concerned in this matter, elaborating and implementing appropriate strategies. The European waste policy is focused on reducing the negative impact of waste and on a better waste management. The prevention of extreme waste generation and the promotion of recycling will increase the efficiency of resources used in the European economies and will reduce the negative impact on the environment.

The amount of waste recorded has increased in many countries, so in this context waste management is gaining more and more importance. At the same time, economic activities are inconceivably linked with the environment (Albu, 2017). Many developed countries use advanced waste management techniques that have proved useful in creating opportunities for recycling and reusing waste. These techniques have allowed an increase in the rate of recycling waste ( $46.59 \%$ of the total waste generated in Germany) and minimized waste disposal on land $(0.64 \%$ of the total waste generated in Sweden) (Eurostat, 2014). The zero-waste concept has been adopted by policy makers because it stimulates sustainable production and consumption, optimal recycling and resource recovery, but zero waste programs are being implemented in many countries without a holistic zero waste strategy. Without integrating and promoting zero waste initiatives through a waste management policy, countries cannot achieve zero waste targets (Zaman, 2015).

Romania is one of the EU countries experiencing difficulties in waste management in terms of collection, transport, treatment, recovery and disposal. The management of municipal solid waste is predominantly driven by the European policy, based on the need to protect human health and the environment and, more recently, on sustainability (Lazarevic, Aoustin, Buclet, \& Brandt, 2010).

The purpose of this paper is twofold. Firstly, the paper aims to present the situation of waste management in Romania, compared with the EU countries that are managing the waste sector in a proper way. For a precise description of the current situation in Romania, we have used secondary data provided by Eurostat.

Secondly, the aim of the paper is to analyse the disparities between the objectives of Romanian national policies and the actual reality to provide general recommendations related to the involvement of all key factors for an optimized waste management. For this, we have conducted an exploratory research based on qualitative interviews with relevant stakeholders. To reach the interviewed persons (experts and representatives of public institutions), we have used a snowball sampling methodology.

Our study analyses the most recent literature and highlights its important aspects. These are the starting points of our research, which is grounded on the most recent studies. The structure of the paper is logically developed, accordingly to the objectives followed. Firstly, it includes a relevant literature review and it continues with the analysis of waste management in Romania in the EU context - which includes the methodology, aspects on municipal waste in the EU, an analysis on waste management practices in Romania, a correlative analysis on some waste indicators, and a waste management stakeholders' perception in Romania. In this way, the analysis on waste management in Romania has a triple perspective, fact which 
provides the novelty of this research: in the context of UE, from the national and local point of view and, respectively, from the stakeholders' viewpoint. The paper is finishing with discussions and conclusions to this research.

\section{Theoretical framework}

Previous studies have approached the waste management in Romania (Almași, 2013) or the projects in this field, focusing on municipal waste management (Popescu \& Pintilie, 2013) and the challenges posed by the selective collection of municipal waste (Târțiu, 2011).

The paper reflects the state of the art in Romania and covers the missing information in research, associated with the involvement of communities in the field of waste management, taking into consideration the formal studies that have investigated the sector of waste management in the early stage of Romania's access to the EU (Scorțar, Lazăr, \& Zagan Zelter, 2009).

Improving the waste management system by increasing the efficiency of activities in this field is a prerequisite for improving the environmental quality of cities (European Commission, 2010a).

The objectives of a sustainable waste management system are to protect the health of the population, to promote the quality of the environment, to develop sustainably, and to provide support for economic productivity. To achieve these objectives, sustainable solid waste management systems need to be fully integrated by local authorities in cooperation with the private sector.

The factors that can contribute to a sustainable waste management system (Karak, Bhagat, \& Bhattacharyya, 2012) are:

- considering waste management a priority at all governmental levels;

- increasing access to resources for waste management departments;

- establishing a computerized data management system on the quantities of waste taken over;

- providing the infrastructure for the extension of basic waste services;

- increasing municipal monitoring and enforcement capacity, especially about the billing of waste services;

- providing information and awareness programs among local businesses and communities to encourage reduced waste generation and acceptance of recycling tools.

Part of the work of recycling waste derived materials is performed by informal collectors, people with low living standards, without a stable paid job. Despite the social and health problems associated with informal recycling, it offers significant benefits in economic terms, and therefore, should be maintained (Wilson, Velis, \& Cheeseman, 2006). The best choice would be to integrate the informal sector in the waste management system, thus aiming to improve the living and working conditions of those involved.

The public education for environmental awareness and the generation of a sense of coproduction and partnership in waste separation have been proven to be the determinants of most success cases in cities from developed countries (Charuvichaipong \& Sajor, 2006). Lack of civic culture correlates with the absence or weakness of autonomous civil society 
organizations, as well as with the non-participatory mode of administration of the municipal authorities.

Public participation is considered essential for the success of recycling schemes. Recycling policy and legislation must gear towards promoting people-centred approaches in recycling with public education as the main driver towards increasing public participation (Bolaane, 2006). Very often, initiatives in the field of waste do not take into account the perceptions and attitudes of the public representatives and the municipal waste recycling schemes. Even though the public is aware of recycling, this does not necessarily translate into participation in recycling initiatives. Other factors, such as limited direct economic incentives and absence of "visible" recycling centres, were found to limit the participation in recycling initiatives.

In order to transform landfills into "gold mines", creative entrepreneurs should have the capacity to understand the emergent properties of deposition, giving rise to a resource base (Johansson, Krook, \& Eklund, 2012). Landfills are embedded in broader socio-technical systems, including technology, policies, culture, norms, markets and networks. Since 2009, several European countries, including Norway, have introduced a total ban on biodegradable landfills (Report from the Nordic Competition Authorities... 2016; ETC/SCP \& European Environment Agency [EEA], 2013b). This can only be accomplished by using Waste Energy facilities in combination with materials recycling (Becidan et al., 2015).

The implementation of Extended Producer Responsibility (EPR) to packaging waste and Waste Electrical and Electronic Equipment (WEEE) is compared and presented as a representative sample of eleven European Union countries (Cahill, Grimes, \& Wilson, 2010). The analysis is based on five indicators: stakeholders and responsibilities, compliance mechanisms, role of local authorities, financing mechanisms and merits and limitations.

Policy-relevant drivers for successful promotion of waste reduction and recycling are identified from two case study cities in Japan (Hotta \& Aoki-Suzuki, 2014). Although incinerators are generally considered a recycling braking factor, in these cases, due to their high costs related to installation, maintenance or replacement, they represent an incentive to reduce waste, suggesting that careful consideration is required when the municipality makes decisions regarding their acquisition. The conclusion would be that better results can be achieved through a more efficient separation at source or other recycling initiatives.

National policies (Wilson \& Williams, 2007) and the application of EU directives at a state level (EEA, 2009) also play an important part in the efforts made by the municipality in recycling. A sustained participation of citizens in the correct separation and collection of recyclable waste depends on attitudes, incentives, presence of children in the household, and information through direct media. A positive attitude toward recycling and information are important factors in explaining recycling participation (Vicente \& Reis, 2008).

The promotion of recycling schemes and a clear information of the communities' members are significant factors of success (McDonald \& Oates, 2003). It is important to evaluate the effectiveness of waste reduction promotion materials and the education and information policies provided by local authorities (Evison \& Read, 2001).

The legal and institutional schemes of several EU Member States have been analyzed, considering all costs and benefits for local authorities through selective collection and assortment (Cunha Marques \& Ferreira DaCruz, 2016). There it have been examined whether the 
industry pays for the net financial cost of recycling preparedness or whether the recovery of extra-recycling costs is through the sale of sorted materials to the consumer through higher prices.

The influence of individualistic attitudinal factors was compared with more communitylevel (or ecological) variables on recycling behaviour in the context of Belfast, Northern Ireland (Kurz, Linden, \& Sheehy, 2007). These results show that the socioeconomic status of the area was the strongest predictor of recycling participation, the recycling attitudes and the sense of community also being important; nevertheless, the general environmental concern is found to have no effect.

To reduce the amount of waste generated, it is important for the population to know the categories of waste that can be recycled and ways to avoid waste generation. Certain laws, as was the ban on the plastic bag, can reduce the amount of waste created (Zaman, 2014).

The amount of municipal solid waste is very variable, and the accumulation of waste depends on several factors. Consequently, the filling level of the tanks is difficult to estimate (Nuortio, Kytojoki, Niska, \& Braysy, 2006). This is a common situation in waste management systems. To overcome this problem, expert systems should be used, which could help to define optimal operational management procedures (Gonçalves, 2014). In this context, access to information on real-time container fill levels through monitoring systems appears to be explored (Ramos, Morais, \& Barbosa-Póvoa, 2018).

Solid waste disposed of daily by the company contains many important constituents. For example, all kinds of valuable metals such as zinc, copper, nickel, chromium, and lead can be found. This brings the need to change the traditional linear patterns followed by our society to recover the valuable resources that man has lost as waste products from daily activities (Burlakovs et al., 2017).

It is the case of several industries. Production, transport, and construction are generating large quantities of waste. For this reason, construction companies must use a systematic approach of waste management (Tambovceva \& Geipele, 2012). Presenting best practices on waste management in various areas such as construction and demolition can be helpful in reducing sustainable waste management. The systematic implementation of these good practices could considerably improve resource efficiency and reduce the environmental impact by: reducing waste generation, minimizing impacts on transport, maximizing reuse, and recycling by improving the quality of secondary materials and optimizing the environmental performance of treatment methods (Gálvez-Martos, Styles, Schoenberger, \& Zeschmar-Lahl, 2018).

Some of the major challenges for society today are the poor and low efficiency of recycling electronic waste, the data of collection infrastructure, as well as the considerable lack of awareness of consumers regarding the potential benefits of electronics recycling, such as environment and energy savings and raw materials. Recycling of electronic products is more complex because they contain several different types of equipment integrated in one another (Tanskanen, 2013).

In developed countries, there are conventions, directives and laws to regulate their disposal, most of them based on extended producer responsibility. Manufacturers take back items collected by retailers and local governments for safe destruction or recovery of materi- 
als. On the other hand, in developing countries, despite the intents of national regulations and hazardous waste laws, most e-waste is treated as general refuse, or crudely processed, often by burning or acid baths, with recovery of only few valuable materials. The burning of this type of waste produces dioxins, furans and heavy metals which have a negative effect on the quality of the environment and on the health of nearby residents (Sthiannopkao \& Wong, 2013). The key to the success of electronic waste management is the development of eco-design devices, the proper collection of electronic waste, the recovery and recycling of materials by safe methods, the elimination of electronic waste by appropriate techniques, the ban on the transfer of used electronic devices to developing countries and raising awareness of the impact of electronic waste (Kiddee, Naidu, \& Wong, 2013). The key to success in terms of e-waste management in the developed countries is EPR and Producer Responsibility Organization (PRO) initiatives (Garlapati, 2016).

A reduction in the amount of waste generated would also be achieved by implementing the economic and circular production systems like those found in nature, such as the water cycle (Cobo, Dominguez-Ramos, \& Irabien, 2018). The scientific papers in waste management field are suggesting the complexity of the process and the diversity of involved stakeholders (Celata \& Sanna, 2014). Thus, stakeholders' engagement in scenario and policy making as well as impact assessment is essential. More extensive measures should also be taken to prevent or reduce waste generation, such as applying eco-design rules that can extend the life of a product, improving its dismantling capacity, or reducing the need for virgin resources by integrating recycled materials into manufactured products. The holistic sustainable framework here could also be applied to manufacturing processes. It may be useful to inform even more decision-makers about the best strategies to follow (Taelman, Tonini, Wandl, \& Dewulf, 2018). The Community-Based Initiatives (CBIs) active in the waste domain tend to have a positive effect in the local communities if they have a relatively strong sense of local identity and existing capacity (Robbins \& Rowe, 2012).

\section{Methodology}

In order to reach the research objectives, we have used data from official statistics (Eurostat), focusing on some important waste management indicators, such as: municipal waste generated, recycling rate of municipal waste, structure of municipal waste by type of treatment. Also, our intention has been to deepen the indicator analysis for Romania, but the Romanian National Institute of Statistics does not currently calculate waste management indicators.

We have analysed the trend of municipal waste generated and recycling rate of municipal waste, comparing the latest value available with a past value. The comparisons of the indicators' values among EU countries are highlighted by using appropriate graphic representations. The structure of municipal waste by type of treatment is represented by graphics showing the latest percentages for the EU countries, but also the dynamics in time of these percentages for Romania. In order to highlight the trends, another graphic representation shows the evolution of municipal waste generated per capita in Romania, compared to the average in the European Union. 
We have also used the correlations analysis - this revealing a predictive relation between two indicators that can lead to a deep analysis. Further, some supplementary information can reveal in which of the above situations we can be, the certitude being that corresponding statistical data vary simultaneously, according to the correlation coefficient. For our research, we used the Spearman correlation coefficient - appropriate for our analysis, this being an analysis of variables without normal distribution and with nonlinear variation.

The data on which the stakeholders' perception in Romania is based were collected between October and March 2017, through direct meetings with initiatives representatives. The research was meant as a post-project activity for the TESS project (Towards European Societal Sustainability). Related to Romania case, we initiate a qualitative research based on 30 semi-structured interviews applied to stakeholders acting in the field of waste (experts and representatives of public/private organizations and CBIs). In order to select the initiatives relevant for the waste management subject, purposeful sampling and snowball sampling techniques have been used. Thus, the authors have interviewed 11 community-based initiatives across North-East and North-West Romania development regions.

To carry out the qualitative research, a semi-structured interview has been used, which has been applied directly to community-initiatives representatives. From the transcript corpus, we have selected a sub-set of descriptive variables from the database for the descriptive analysis, covering initiatives' characteristics and their input regarding waste management policies and good practices. We have identified circa 10 variables relevant for the research objective.

A first key descriptor was the number of people involved in the initiative, which was covered by the question "who actively contribute or are associated in any way with the initiative (they may work there, participate in meetings or decision making, give/spend time, contribute to activities, running events, etc.)". The answers to this question varied quite substantially as initiatives varied not only in size, but also in their definition of active participants. $75 \%$ of groups had less than 50 active participants.

Regarding the legal form, the initiatives in Romania are generally registered Non-governmental organization (NGOs), compared with other countries from Europe, where the community initiatives are charities or trusts. The decision-making process involves the general assembly, but the decisions are mainly taken by the board, with members selected by vote by the general assembly.

In the field of waste, the 11 initiatives analyzed have focused on:

- Food "saving" (both in food and waste) (3 initiatives);

- Promoting waste reduction and recycling (7 initiatives);

- Litter-picking (2 initiatives);

- Recirculating unwanted items (2 initiatives);

- Repairing and upcycling items (2 initiatives), including teaching repair skills.

Some of these $11 \mathrm{CBI}$ are involved in one or several activities from those mentioned above. Only few CBIs have paid employees, and the average number is of 3 staff members, serving the initiative on full-contract. As a general remark, the number of employees depends on the number of active projects implemented by the initiative. Regarding the agedistribution, most of the initiative staff members are under 30, showing a high involvement 
and commitment of younger generation to the theme of waste management and environment protection.

Overall, CBIs tend to be young organizations, with many of them under 10 years old. Without a longitudinal dataset, it is hard to tell whether this is because few initiatives last beyond 10 years or because there have been many more initiatives started in the past 10 years. The financial resources of CBIs are ensured by fees/subscriptions/membership's dues and public grants. As well, sponsorship is an important financial source for 6 from the $11 \mathrm{CBIs}$.

\section{Analysis of current municipal waste management in Romania in the European Context}

\subsection{Brief overview of the municipal waste management in the European Context}

In order to achieve a sustainable use of natural resources, the EU is developing tools to monitor progress made by Member States and economic sectors. Reducing the negative impact of using natural resources can be provided only in terms of increasing awareness of public and stakeholders on these issues.

At the EU level, the strategic documents of the European policies which have an impact on waste management include (Table 1).

Table 1. Strategic documents of European policies impacting on waste management and their main actions (source: elaborated based on European Commission, 2018b)

\begin{tabular}{|c|c|}
\hline $\begin{array}{l}\text { Strategic documents of European policies } \\
\text { impacting on waste management }\end{array}$ & Main actions \\
\hline $\begin{array}{l}\text { - Thematic Strategy on Waste Prevention and } \\
\text { Recycling }\end{array}$ & $\begin{array}{l}\text { Establishes guidelines reducing negative environmen- } \\
\text { tal impact caused by waste from generation to final } \\
\text { disposal }\end{array}$ \\
\hline $\begin{array}{l}\text { - Sustainable Development Strategy of the } \\
\text { European Union }\end{array}$ & $\begin{array}{l}\text { Creates sustainable communities capable to manage } \\
\text { and use resources efficiently }\end{array}$ \\
\hline $\begin{array}{l}\text { - Project of the Seventh Environment Action } \\
\text { Program }\end{array}$ & $\begin{array}{l}\text { Promotes integration of environmental requirements } \\
\text { into all policies and actions and forms the environ- } \\
\text { ment Sustainable Development Strategy }\end{array}$ \\
\hline $\begin{array}{l}\text { - Communication from the Commission to } \\
\text { the European Parliament, the European } \\
\text { Economic and Social Committee of the } \\
\text { Regions }\end{array}$ & $\begin{array}{l}\text { Provides a roadmap to a resource-efficient Europe in } \\
\text { terms of energy }\end{array}$ \\
\hline $\begin{array}{l}\text { - Thematic Strategy on the Sustainable Use of } \\
\text { Natural Resources }\end{array}$ & $\begin{array}{l}\text { Reduces the negative environmental impact gener- } \\
\text { ated by the use of natural resources in developed } \\
\text { economies }\end{array}$ \\
\hline
\end{tabular}

According to the Eurostat definition, municipal waste consists of waste generated by households to a large extent, but may also include similar waste generated by small businesses and public institutions and it is collected by the municipality; this part of municipal waste may vary from municipality to municipality and from country to country, depending on the local waste management system. For areas not covered by a municipal waste collection scheme, the amount of waste generated is estimated. 
On an average, in 2016 the EU citizens generated approximately 9\% less waste than in 2007, according to Eurostat. Waste volumes increased only in seven Member States of the European Union (Greece, Slovakia, Czech Republic, Croatia, Lithuania, Germany, and Latvia).

Romania is part of the new waste management system, in which most of the collected municipal waste is disposed in landfills, recycling and recovery operations being used to a very limited extent. Efforts and significant investments have been made to align the local policies and practices with the community acquis (ETC/SCP \& EEA, 2013a). The situation has been evolving rapidly and positive changes are visible, but the main method of waste disposal is still storage.

As seen in Figure 1, there are considerable differences among Member States. For example, in 2016 Romania produced an amount of $261 \mathrm{~kg}$ of waste per capita, whereas Denmark produced nearly 3 times more $(777 \mathrm{~kg})$.

Apparently, the figures from the chart above represent a positive indicator for Romania. Despite that, we must mention that important quantities of waste are not collected and reported. As well, the population that lives in urban area has a lower share in total $(56.3 \%)$ than in other EU countries (România în cifre. Breviar Statistic, 2017).

The recycling rate in the EU countries increased in 2016, as compared to 2007. As it can be seen in the chart below, in only few European countries the recycling rate was lower in 2016 than in 2007. These countries are: Spain, Greece, Belgium and Austria (Figure 2).

In 2016 the recycling rate of the municipal waste in the EU was $45.8 \%$, increasing from $35 \%$ in 2007. The European Commission set new targets regarding the recycling rate of municipal waste: $55 \%$ by 2025, 60\% by 2030 and 65\% by 2035 (European Commission, 2018a). In Romania, in 2014, about $5 \%$ of the total waste generated was recycled (Eurostat, 2016),

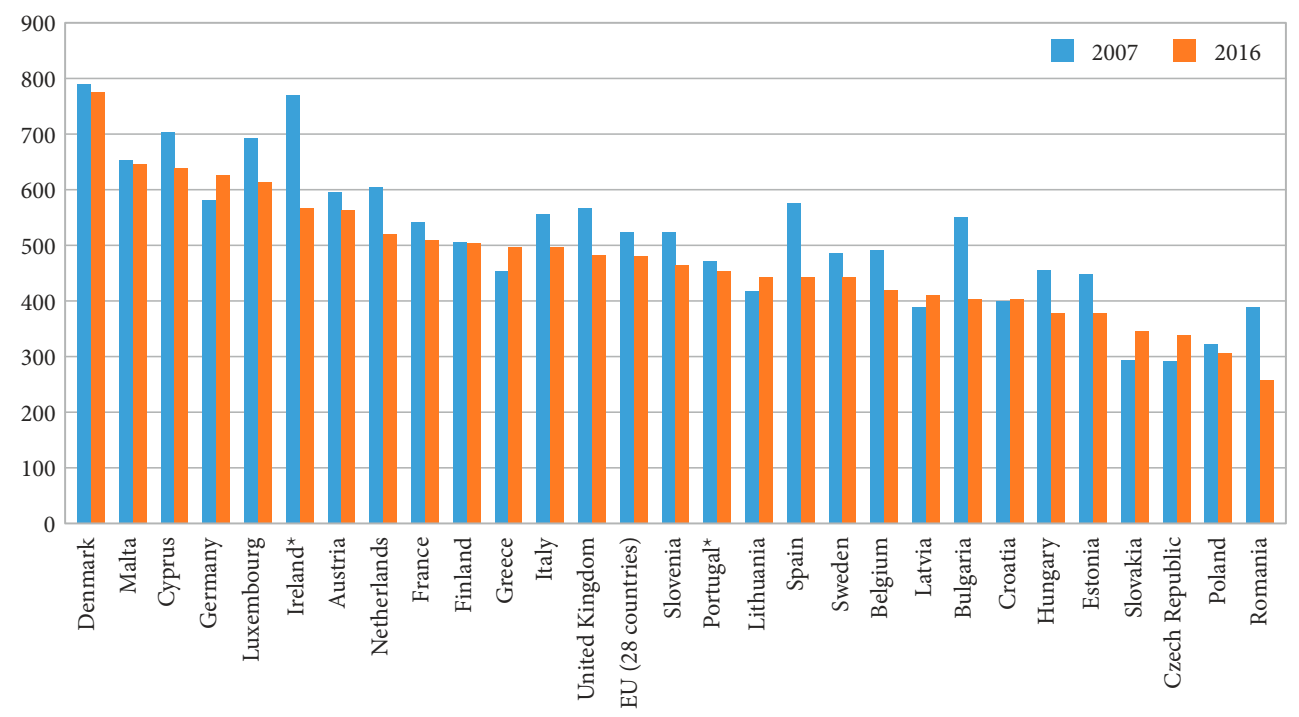

Figure 1. Municipal waste generated in EU countries (kilograms per capita)

(source: Own elaboration based on Eurostat, 2018)

Note: ${ }^{\star} 2014$ for Ireland and Portugal. 
and selective collection was underfunded. In the chain of waste management, a lot of components are important for reaching the final result. All these components should be interlinked for a proper functionality. In these circumstances, among other causes, the population's lack of information leads to a weak behaviour; Romania ranks among the last countries in the European Union regarding municipal waste recycling rate, including garbage generated by households (Eurostat, 2013).

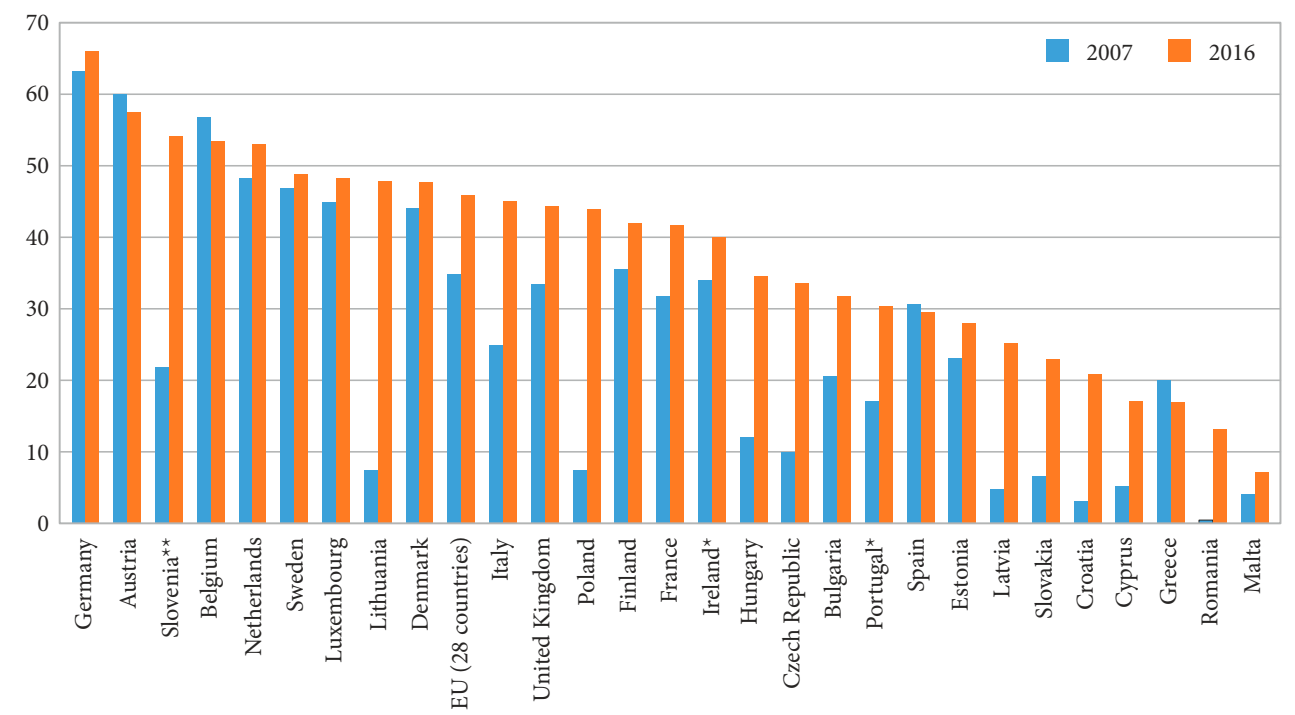

Figure 2. Recycling rate of municipal waste in EU countries (source: Own elaboration based on Eurostat, 2018)

Notes: ${ }^{\star} 2014$ for Ireland and Portugal, ${ }^{\star \star} 2015$ for Slovenia.

There are significant differences among waste management systems in the EU countries (Figure 3). Thus, there are countries where most of the waste is going to landfill, as it happens in Malta (91.80\%), Greece (82.46\%), Cyprus (81.35\%), Romania (79.8\%) or Croatia (78.44\%), while in other countries most of the waste is treated by other operations such as incineration, recycling, composting and digestion. In 2016 there were countries like Sweden $(0.64 \%)$ and Belgium $(0.81 \%)$ in which less than $1 \%$ of waste reached to the landfill. In 2014, in Romania, $82.02 \%$ of the waste reached to the landfill, which is a very high value compared to the average registered at the level of the European Union (24.69\% of waste generated).

\subsection{Correlative analysis regarding environmental tax and recycling in the EU countries}

A levy depending on the amount of waste arriving at the landfill may result in an increase in the recycling rate. In Romania, only from January $1^{\text {st }}, 2016$ a fee of 80 lei per tonne (about 18 euro per tonne) for depositing waste to landfill came into force; the fee increased to 120 lei per tonne (about 27 euro per tonne) in 2017. The effects of applying a fee for waste disposal at 


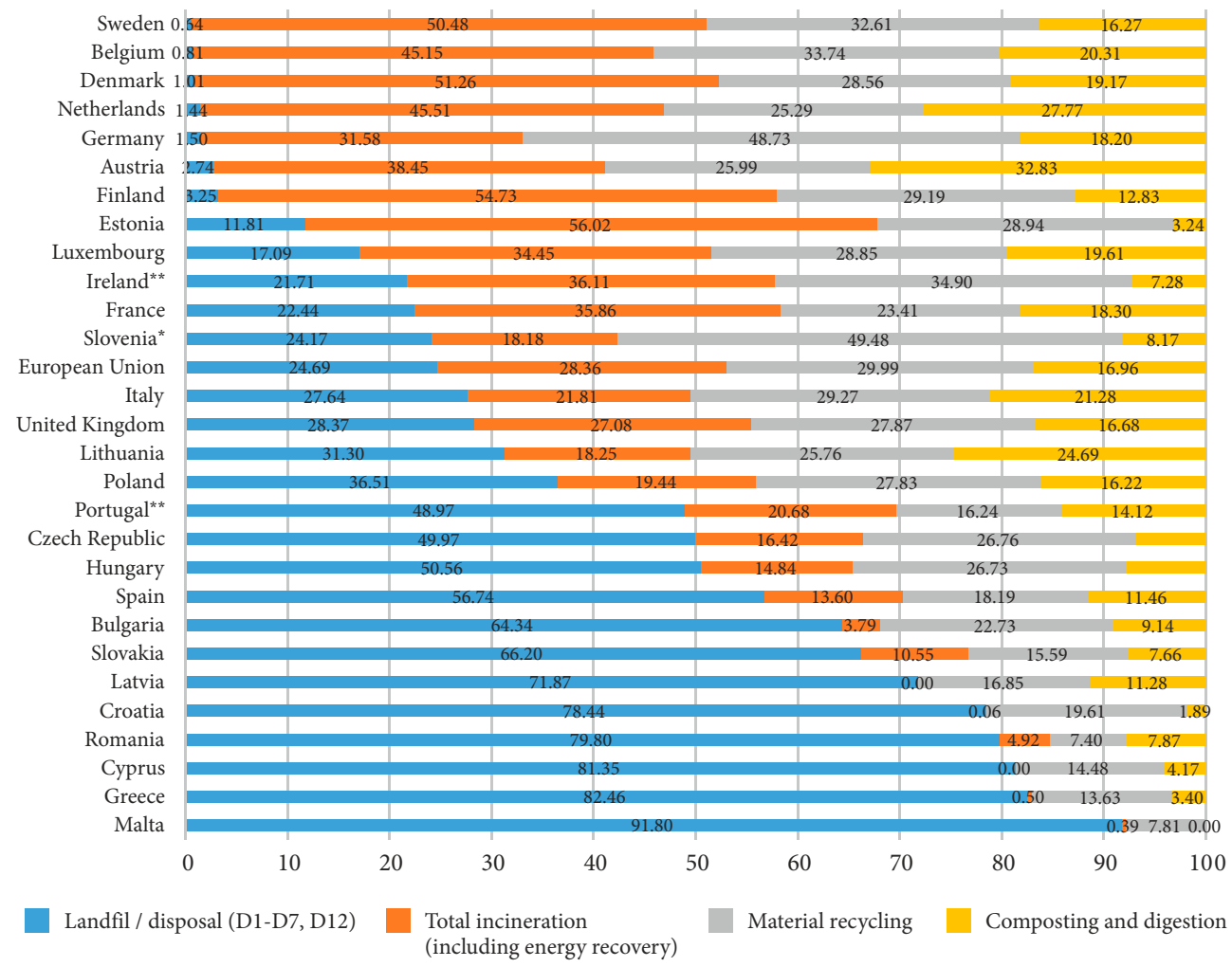

Figure 3. Structure of municipal waste by type of treatment, in UE in 2016

(source: Own elaboration based on Eurostat, 2018)

Notes: only ${ }^{\star} 2015$ data, ${ }^{* *} 2014$ data available

the landfill are already visible in countries like Holland and Belgium (Bartelings, van Beukering, Kuik, Linderhof, \& Oosterhuis, 2005). If the landfill is more expensive, there will be a decrease in the amount of waste, encouraging recycling (Fischer, Lehner, \& McKinnon, 2012).

Based on the analysis carried out regarding the year 2014 at the level of the EU countries, the data sets that represent the amount of material recycling and Environmental Tax Revenues have proved that there is a connection between the two indicators.

In the EU countries, there is a strong correlation between the environmental tax revenues and the amount of material recycling. The obtained value (0.926) for Spearman correlation coefficient indicates a direct link between the variables analysed at the level of the $28 \mathrm{EU}$ countries (Table 2). In countries where the environmental tax is high, there is a prerequisite for a high amount of material recycling, in comparison with countries where an environmental tax is low and only a low amount of waste is recycled.

At the same time, it can be seen that in the EU countries, there is a correlation between the environmental tax revenues and landfill/disposal rates. The obtained value $(-0.515)$ for Spearman correlation coefficient indicates an indirect link between the variables analysed at the level of the $28 \mathrm{EU}$ countries (Table 3). 
Table 2. Correlations between environmental tax revenues and the amount of material recycling (source: Own elaboration based on Eurostat data, 2018)

\begin{tabular}{|l|l|l|c|c|}
\hline \multicolumn{2}{|l|}{} & $\begin{array}{c}\text { Environmental } \\
\text { tax revenues }\end{array}$ & $\begin{array}{c}\text { Amount of } \\
\text { material_recycling }\end{array}$ \\
\hline \multirow{3}{*}{$\begin{array}{l}\text { Spearman's } \\
\text { rho }\end{array}$} & $\begin{array}{l}\text { Environmental } \\
\text { tax revenues }\end{array}$ & Correlation Coefficient & 1.000 & $0.926^{* *}$ \\
\cline { 3 - 5 } & Sig. (2-tailed) & $\cdot$ & 0.000 \\
\cline { 2 - 5 } & $\mathrm{N}$ & 28 & 28 \\
\cline { 2 - 5 } & $\begin{array}{l}\text { Amount } \\
\text { of material_recycling }\end{array}$ & Correlation Coefficient & $0.926^{* *}$ & 1.000 \\
\cline { 3 - 5 } & Sig. (2-tailed) & 0.000 &. \\
\cline { 2 - 5 } & $\mathrm{N}$ & 28 & 28 \\
\hline
\end{tabular}

Note: ${ }^{*}$ Correlation is significant at the 0.01 level (2-tailed).

Table 3. Correlations between environmental tax revenues and landfill/disposal rate (source: Own elaboration based on Eurostat data, 2018)

\begin{tabular}{|l|l|l|c|c|}
\hline \multicolumn{2}{|l|}{} & $\begin{array}{c}\text { environmental } \\
\text { tax revenues }\end{array}$ & $\begin{array}{c}\text { Landfill/disposal } \\
\text { rate }\end{array}$ \\
\hline \multirow{3}{*}{$\begin{array}{l}\text { Spearman's } \\
\text { rho }\end{array}$} & $\begin{array}{l}\text { environmental tax } \\
\text { revenues }\end{array}$ & Correlation Coefficient & 1.000 & $-0.515^{* *}$ \\
\cline { 3 - 5 } & & Sig. (2-tailed) & $\cdot$ & 0.005 \\
\cline { 3 - 5 } & $\mathrm{N}$ & 28 & 28 \\
\cline { 3 - 5 } & Landfill/disposal rate & Correlation Coefficient & $-0.515^{* *}$ & 1.000 \\
\cline { 3 - 5 } & Sig. (2-tailed) & 0.005 &. \\
\cline { 3 - 5 } & $\mathrm{N}$ & 28 & 28 \\
\hline
\end{tabular}

Note: ${ }^{\star \star}$ Correlation is significant at the 0.01 level (2-tailed).

The value $(-0.515)$ for the correlation coefficient between the two variables is negative. This means that a high amount of environmental tax revenues corresponds to a smaller rate of waste deposited at the landfill. In countries where the amount of environmental tax revenues is small, a significant rate of waste is deposited to the landfill.

Preventing waste production is a top priority in the management hierarchy, but so far, the results have not been satisfactory. There is a large gap between the political objectives of prevention expressed in various EU directives and the reality of continuing growth in waste generation (European Commission, 2016). Amounts of waste, according to forecasts, will continue to grow, so the environmental impact will also grow with them. Usually, the increasing economic activity means an increase in waste generation, and as economic growth is the main policy goal across Europe, often it is hard to find politically acceptable instruments to limit the actual production of waste (European Commission, 2010b). Experience shows that a successful prevention activity requires various tools. However, domestic waste reduction is a complicated task, as it involves reduced consumption in general and changes in the consumption patterns, which, in turn, requires considerable changes regarding habits and lifestyles. Enterprise-level actions can be taken in the sphere of extraction and processing of raw materials and in the design and manufacture of appropriate products. Programs introducing cleaner technologies have proven useful for reducing waste production in the industry. 


\subsection{Waste management policies and relevant stakeholders in Romania}

\subsubsection{Waste management in Romania. Recent evolutions}

Turning waste into resources is a key factor for a sustainable economy. The objectives and targets set by the European legislation aim at improving waste recycling and stimulating innovation. By improving waste management, the environmental health issues will be further tackled, and greenhouse gas emissions will be significantly reduced. At the same time, the negative impact of waste will be reduced, thus limiting water, air and landscape pollution caused by landfills. For example, from organic fractions, such as food waste and green waste generated from households, which are an important part of waste, one can produce a high quality natural fertilizer for home use (Zorpas, Lasaridi, Pociovălișteanu, \& Loizia, 2018). The evolution of municipal waste generated per capita in Romania, compared to the average in the European Union, during the period 2007-2016, according to Eurostat data, indicates a decrease by 2008 in the amount of waste generated per capita (Figure 4).

The average amount of municipal waste generated per capita is lower in Romania, compared to the European average, but the waste production that remains outside the statistical records should also be considered. To achieve a sustainable use of natural resources, the EU is developing tools to monitor the progress made by the Member States and the economic sectors.

In Romania, most of the collected municipal waste is disposed in landfills, recycling and recovery operations being used to a very limited extent. Efforts and significant investments were made to align the local policies and practices with the acquis communautaire. The situation has been evolving rapidly and positive changes are visible, but the main way of waste disposal is still storage. Figure 5 displays the type of treatment of municipal waste from 2007 to 2014.

Important progress can be observed in the evolution of the methods used over the years: the landfill disposal decreased to $82.02 \%$ in 2014 from $99.42 \%$ in 2007 . Still, waste management in Romania remains a challenge. According to the investigations carried out, incinerators that convert waste into energy do not exist due to high waste humidity caused by the

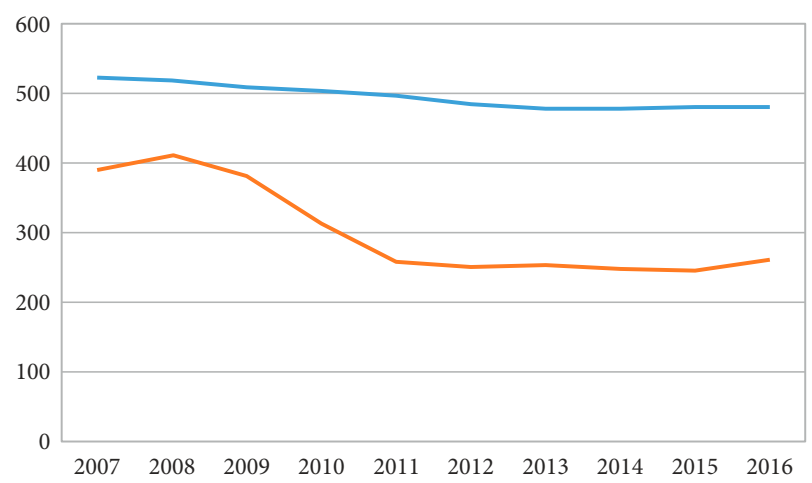

Figure 4. The evolution of municipal waste generated per capita in Romania, compared to the average in the European Union, during 2007-2016 (source: Own elaboration based on Eurostat data) 
mixed collection of biodegradable and non-biodegradable waste as well as to the negative public opinion on incineration facilities (Căilean Gavrilescu \& Teodosiu, 2016). Generally, in the EU there is a certain aversion to the construction of waste incineration plants. Waste treatment using a Waste-to-Energy (WTE) plant is avoided, not being considered an alternative to the landfill (Cucchiella, D’Adamo, \& Gastaldi, 2017). Achieving by 2020 a recycling rate of $50 \%$ of municipal waste assumed by Romania, like other EU countries, will require the functioning not only of the representatives of public authorities, but also of viable community initiatives in the field of waste. Such an objective could indeed be achieved only through the involvement of all communities, at the local level. This will require active involvement of citizens and other relevant actors (public institutions - city hall, hospitals, schools - environmental authorities, recycling companies, informal collectors, NGOs, media, public, etc.) in all phases/stages of designing and implementing the strategy for waste management at a local level.

The waste management system can be improved by implementing measures in order to reduce the amount of waste. A responsible implementation of waste legislation can be considered essential in the existence of an efficient management of waste, but this requires a numerous enough staff, prepared to implement the appropriate measures accordingly and penalize irregularities when they occur. Ensuring an appropriate infrastructure for waste management (collection, storage, transport, etc.) is one of the requirements for achieving a type of waste management according to EU directives (OECD, 2013). Moreover, organizing frequent public awareness campaigns on the importance of separate collection of waste categories will ultimately determine every individual to undergo profound changes regarding the attitudes towards the selection of waste.

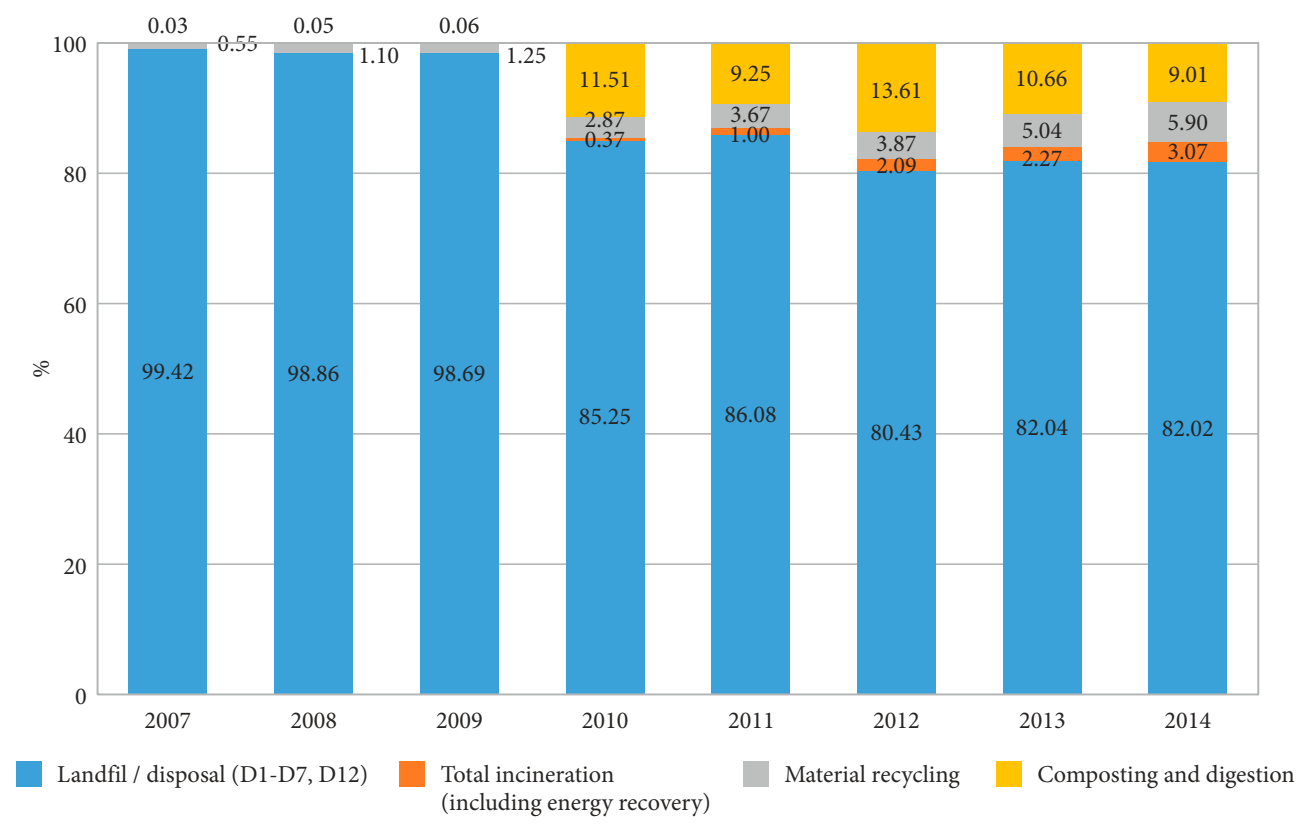

Figure 5. Structure of municipal waste by type of treatment, in Romania, during 2007-2014 (source: Own elaboration based on Eurostat data, 2018) 
In accordance with the Strategic documents of European policies impacting the waste management and National waste management strategy, the Romanian Ministry of Environment must assume a central role in the management and prevention of waste. Fulfilling this role requires prioritizing efforts to manage waste in accordance with the principle of waste hierarchy (prevention, preparation for reuse, recycling, other recovery - e.g. energy recovery, disposal). In this respect, it is necessary to develop measures to encourage waste generation prevention, reuse waste type packaging, promoting sustainable use of resources.

The Ministry of Environment must work with the business sector and enterprises that harness waste to find solutions to increase the recycling rate and improve the quality of the recycled materials. Given that, waste cannot only be recycled, but it requires finding optimal solutions that lead to obtaining energy from waste. The evaluation of results will be ensured by organizing national databases through a more efficient process to monitor the activity, carried out by the subordinated institutions.

\subsubsection{Legislation related to waste management}

The waste management is based on the Romanian National Strategy and on the Waste Management National Plan. The national policy on waste management must underwrite European policy objectives in terms of waste prevention and aim to reduce resource consumption and practical application of the waste hierarchy. The principle of preventive action is one of the principles underlying the Emergency Ordinance no. 195/2005 on environmental protection, as amended and supplemented, Directive 2008/98/EC on waste and repealing certain directives transposed into national law by Law no. 211/2011 on waste regime. To support sustainable development, objectives, measures and waste management monitoring indicators were proposed through the Waste Management National Plan. A verification of the accomplishment degree of these measures, as well as of the strategic objectives of the management program will be part of the annual monitoring report prepared by the Ministry of Environment (Waste Management National Plan (Planul Național de Gestionare a Deșeurilor, 2018)).

The Romanian legislation on waste management comprises several normative acts, their provisions being in line with the EU legislation. Next, we present the main normative acts in the field.

Law no. 211/2011 on the waste regime establishes a legal framework for the treatment of waste in Romania. It aims to establish the necessary measures to protect the environment and the health of the population by preventing or reducing the adverse effects of waste generation and management and by reducing the overall effects of resource use and increasing the efficiency of their use. It includes strengthening the measures to be taken to prevent and reduce the environmental impact of waste generation and management, establishing also the responsibility for waste management. The central public environmental authority adopts programs to prevent waste generation at the national level.

Government Decision no. 1470/2004 on the approval of the Waste Management National Strategy and the Waste Management National Plan creates the necessary framework for the development and implementation of an integrated and efficient waste management system.

Government Decision no. 349/2005 on the storage of waste, as subsequently amended, creates the legal framework for the carrying out of the waste storage activity and the related 
activities regarding the new and the existing deposits, under conditions of environmental protection and population health.

Government Decision no. 621/2005 establishes rules for the management of packaging and packaging waste to prevent or reduce the environmental impact.

Government Decision no. Regulation 1037/2010 aims, on the one hand, to prevent the generation of electrical and electronic equipment waste and, on the other hand, to reuse, recycle and provide other forms of recovery so that the volume of waste eliminated can decrease.

Government Emergency Ordinance no. 196/2005 on the Environmental Fund establishes that Environmental Fund management is the responsibility of the Environmental Fund Administration. The Environment Fund is an economic and financial instrument designed to support and implement projects and programs for environmental protection and to achieve the European Union's environmental and climate change objectives in accordance with the legal provisions in force; according to the Emergency Ordinance no. 196/2005, the annual target for reducing the quantities of municipal waste disposed of by storage, is as follows: 25\% for 2017, 35\% for 2018, and 45\% as from 2019 (Government Emergency Ordinance no. 196/2005, 2005).

The most recent normative act is the Government Emergency Ordinance no. 74/2018 for amending and completing Law no. 211/2011 on the waste regime, Law no. 249/2015 on the management of packaging and packaging waste, and the Government Emergency Ordinance no. 196/2005 on the Environmental Fund. Thus, the local public administration authorities or the administrative-territorial subdivisions of the municipalities, respectively their intercommunity development associations, will have a series of obligations, such as:

- Providing a separate collection system for municipal waste;

- Achieving a level of readiness for re-use and recycling of at least $50 \%$ of the total mass generated of municipal waste by 31 December 2020;

- Complying with the performance indicators for the sanitation service activities and the application of penalties for not reaching them (from January 1st, 2019);

- Complying with the "pay for what you throw" economic tool, based on the volume of waste, collection frequency, weight and/or number of customized collection bags (from January 1st, 2019);

- Complying with the "Extended Producer Responsibility" principle, by covering local budget costs by the organizations implementing the obligations regarding manufacturer's extended responsibility.

In order to encourage a circular economy, pressure is put on the sanitation agents: for the quantities of waste removed by storage, a penalty should be paid.

City Halls must be actively involved in implementing the new waste management provisions in accordance with their obligations. They continue to be direct or indirect providers of public services to the population and beneficiaries of the sanitation contracts, and a periodic control of the implementation of the measures is the responsibility of the competent authorities that will apply sanctions and fines in case of non-compliance with the legal provisions. 


\subsubsection{Stakeholders' involvement and responsibilities}

The environmental policy at the national level is set by the Ministry of Environment, which takes care of the environmental protection, green economy, biodiversity, protected natural areas, climate change, acting as a state authority, synthesis, coordination and control in these fields, directly or through technical bodies, specialized authorities or public institutions. It elaborates the specific strategy and regulations for development and harmonization of these activities within the general policy of the Government, ensures and coordinates the implementation of the Government strategy in its fields of competence, fulfilling the role of state, synthesis, coordination, regulation, monitoring, inspection and control authority in these fields (Ministerul Mediului, 2018). The Ministry of Environment has the mission to protect the environment and natural resources to ensure current and future generations with a clean environment, in harmony with economic and social progress. The ministry controls the National Environmental Protection Agency and the National Environmental Guard.

The National Environmental Protection Agency is headed by a president and is the specialized institution of the central public administration, subordinated to the Ministry of Environment and competent to implement policies and legislation in the field of environment protection. The National Environmental Protection Agency (including the 42 county agencies) acts to provide the population with a healthy environment in harmony with the economic development of the country. The responsibilities of the National Environmental Protection Agency are: strategic environmental planning, monitoring of environmental factors, authorization of activities with an environmental impact, implementation of environmental legislation and policies at the national and local level, reporting to the European Environment Agency (air quality, climate change, protected areas, soil contamination, water) (Agenția Națională pentru Protecția Mediului, 2018).

The National Environmental Guard is a public institution subordinated to the Ministry of Environment and functions as a specialized body of the central public administration, being headed by a General Commissariat. The National Environmental Guard is a specialized inspection and control body that can take measures to sanction, suspend, or terminate the activity as a result of the pollution and deterioration of the environment for non-compliance with the conditions imposed by the regulatory acts (Garda Națională de Mediu, 2018).

The Environmental Fund Administration is a public institution with legal personality, financed entirely from its own revenues, which provides financial support for the implementation of projects and programs for environmental protection, established according to the European principles "polluter pays" and "producer responsibility"; it functions as a specialized body of the central public administration and is coordinated by the Ministry of Environment (Administrația Fondului pentru Mediu, 2018). Through the Environmental Fund Administration, there is a possibility to finance eligible projects. In this context, significant sums have been earmarked from the budget of the Environment Fund for programs and projects for environmental protection.

According to legislation, public institutions (i.e. city halls, prefectures, local councils, or other territorial administrative units) have certain environmental obligations, including a series of environmental impact of waste monitoring and control of the following categories of activities (Care sunt obligatiile de mediu ale institutiilor publice?, 2018): 
- Generating, collecting, storing, transporting and treating domestic and construction waste, and implementing their management plan of these;

- Eliminating production and hazardous waste and implementing the local management plan of these;

- Providing facilities and installations for storing and neutralizing domestic and construction waste, and those for the disposal of industrial and hazardous waste.

Additional to public institutions in the last decades the CBIs and NGOs started to play an important role in waste management in Romania. As an example the initiative "Let's do it Romania" has mobilized more than 365,000 people all over the country for waste collecting campaigns. The activities undertaken by CBIs in the field of waste are quite numerous in Romania, but their effects are hard to quantify. Often, the activities of the CBIs are reduced to rare events where people participate, with no further changes in the behavior of population regarding recycling. A synthesis of the stakeholders involved in the waste management system in Romania at the national, county and local levels is shown in Figure 6.

In accordance with strategic documents of European policies impacting on waste management and National waste management strategy, the Romanian Ministry of Environment must assume a central role in the management and prevention of waste. Fulfilling its role requires prioritizing efforts to manage waste in accordance with the principle of the waste hierarchy (prevention, preparation for reuse, recycling, other recovery - e.g. energy recovery, disposal). In this respect, it is necessary to develop measures to encourage waste prevention, reuse waste type packaging, and promotion of sustainable use of resources. Achieving these targets will be possible only by improving the services offered to the public and business sector. A more effective collaboration with the local public authorities, the business sector, CBIs and NGOs will lead to the improvement of the collection and treatment of waste.
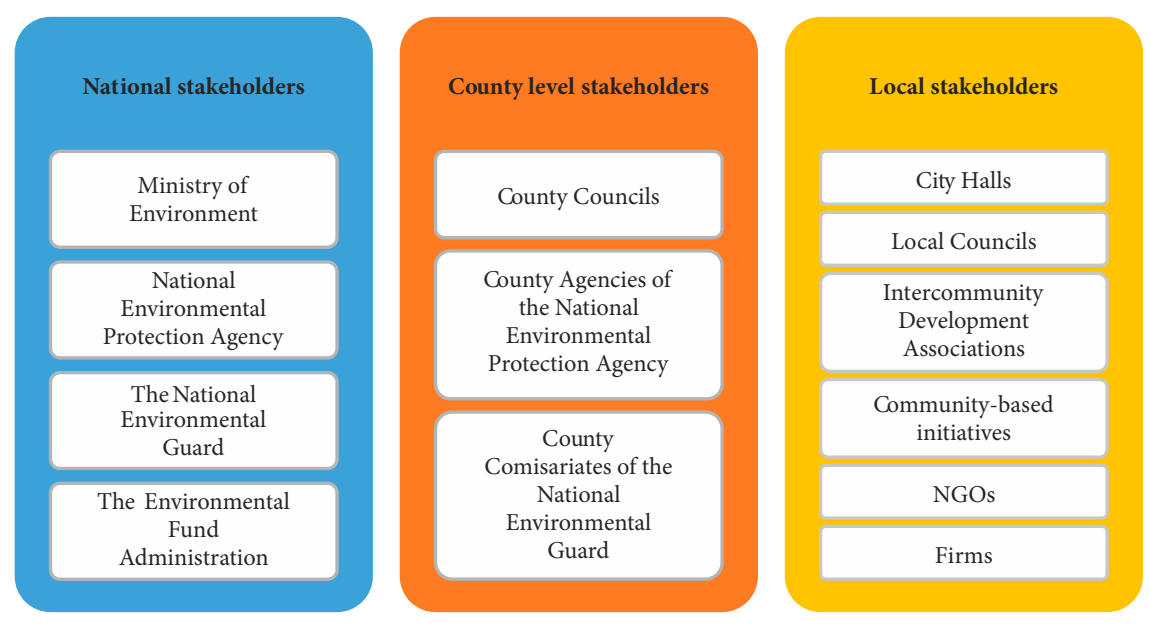

Figure 6. Stakeholders involved in the waste management system in Romania at national, county and local levels 


\subsection{Waste management in Romania. A stakeholders' perspective}

Ensuring a sustainable system of waste can only be achieved by involving all stakeholders, generators of waste processors, formal and informal agents, nongovernmental organizations and financial institutions (Joseph, 2006).

To understand the stakeholders' contribution and the factors that have a contribution on efficient waste management, we conducted qualitative research based on 30 semi-structured interviews in 2016, involving stakeholders acting in the field of waste (experts and representatives of CBIs and institutions). We wanted to identify objectives of waste minimization initiatives, waste reduction campaigns, examples of initiatives taken by municipalities for waste reduction, role of stakeholders and national policy. We used NVivo software package for the analysis of qualitative data, such as transcripts of in-depth interviews, focus groups and field notes.

The qualitative analysis of these interviews has revealed that, according to the activists, the community involvement can generate radical changes only in certain cases. Protests must be done peacefully, and change should come from each individual behavior change. Some members of the initiative claim that it is difficult to make radical changes in Romania because this would mean changing the entire management system, which is not easy at all. Mentalities are the most difficult to change in the Romanian society. Thus, those who advocate for environmental protection lose their enthusiasm slowly because of bureaucracy and finally give up more fighting with the system. Environmental activists, who prefer to start a direct confrontation with the system, quickly deplete their resources to fight. The environmental conservation attitude is reflected in the attitude towards the way of producing social change, which might intervene in efficient waste management. The implementation of a policy for efficient waste management should be made gradually, taking into consideration all the effects that might occur.

Some of the respondents felt that the success of the actions of the CBIs is hindered by the community itself. People from local communities have different views on the concept of green economy. Many are reluctant to actions aimed at environmental protection. People are skeptical about the success of actions that protect the environment. Some of the respondents have suggested that there are personal interests that often lie behind social responsibility campaigns. The population is sometimes suspicious when exhibiting social responsibility. They sometimes associate these actions with some interests in creating a favorable image. Sometimes these campaigns are perceived as a distraction from other issues of public interest is desired.

Most of the respondents believe that the lack of ecological culture among local communities is the main impediment in the development of initiatives. The environmental education is considered insignificant and the feedback from the community is often negative. The actions of the initiative are not always a priority interest of the community. The respondents would want that the actions can be undertaken within the organization to determine social and economic changes in society, but first is the need of making people aware of environmental issues to get behavior change. The contribution to social change initiatives is limited by the insufficient knowledge of the public on the concepts of ecology. 
The interviews with stakeholders acting in the field of waste have revealed that the superficial involvement of the authorities in implementing the necessary measures has resulted in a diminished impact on society. Moreover, the difficulty of the CBIs to attract volunteers to be actively involved has reduced the ability to generate the desired changes in society.

The declarative-only involvement of authorities regarding the environmental protection decreased the enthusiasm of volunteers involved in the initiatives. The feeling that they are "tilting at windmills", made some volunteers to abandon their work. Moreover, bureaucracy and the lack of transparency regarding the actions taken by authorities hinder the initiatives that could have a major impact on society. Change of mindset and attitude of the population cannot occur suddenly, but on the long run. Very few people will remain motivated to achieve the goals of the community-based initiative given that the results are visible after a very long time. Some members lose interest in the goals of the organization due to the difficulties they have experienced.

Other issues highlighted by the stakeholders, in terms of the lack of adequate public support in the field of waste, are highlighted in Figure 7.

The application of clear legislative measures and the discouragement through penalties of large deviations from the rules of separate waste collection can produce the expected effect among the population and economic entities. Often, controlling activities that affect the environment collide with the existence of understaffed institutions acting in the environmental field.

The CBIs should be more actively involved in the field of waste, surpassing their current stage. The lack of infrastructure in the field of waste creates prerequisites for the emergence and multiplication of CBIs in this field.

Every citizen should be aware of the fact that if you do not collect selectively the waste generated daily (paper packaging and cardboard, plastic containers, glass or metal, electrical and electronic waste batteries) and throw them into bins or mixed garbage containers, this will reflect very soon, not only in high levels of pollution affecting human health and the

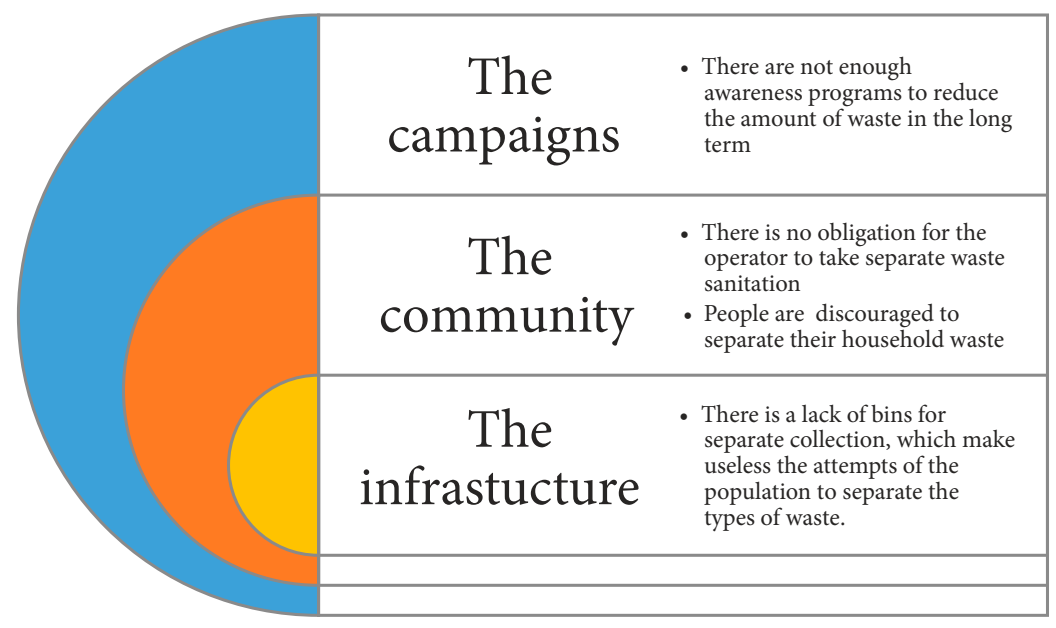

Figure 7. The public support in the field of waste 
environment, but also in the price we have to pay for new products for a material sanitation service (Al-Salem, Lettieri, \& Baeyens, 2009). Contributing to the conservation and reuse of the existing resources is more than proof of good civic policy, and this is exactly what every citizen should do to protect our environment. The reduction of stored waste, and the protection of natural resources involve the implementation of selective waste collection and reusable waste recovery and recycling. These measures will result in a modern waste management contributing to the reduction of the amount of landfilled waste by establishing an appropriate system to treat each type of waste in order to protect the environment. The implementation of the legal provisions in current economic activities and local government, is expected to improve the environmental quality and human health.

Reducing the negative impact of a weak waste management can be achieved only in terms of increasing awareness of public and stakeholders on these issues. The set targets will be achieved only by improving the services offered to the public and business sector. In this context, CBIs have a duty to implement public awareness programs regarding the importance of selective waste collection, thus educating citizens about waste reduction.

\section{Discussions and conclusions}

The paper highlights the importance of cooperation among all the stakeholders for an effective waste management system. Based on the results of our research, the development and implementation of measures meant to change behavior in the direction of reducing, reuse, recycling and recovering of waste will accelerate the transition towards a circular economy with zero waste. Moreover, community participation in waste collection and separation is very important and can be achieved by: communication strategies among community members and stakeholders; implication of representative local leaders and CBIs in stimulating community participation; supporting community-based initiatives by local authorities, or cooperation between the CBI and the local authorities according to formal agreements with stakeholders (Subash, 2006).

Legislation can be implemented, but there must be assisted by control and correction procedures. Without such a mechanism, the rules alone will not work. If there is no communication with the citizens on selective collection and recycling, we cannot know what, when, where, and how it is collected. People need to understand clearly why it is necessary to select waste. Thus, legal instruments and economic sanctions, awareness, communication, and responsibility towards a cleaner environment are all very important.

In order to make the effects of community-based initiatives in the field of waste visible at the national level, it is necessary:

- to ensure transparency when municipalities sign contracts with sanitation companies for the next period;

- to include the obligation to collect waste selectively in these contracts;

- to provide the infrastructure for waste selection at source, near local households, and

- to close the waste pipes located inside buildings and replace them with exterior ones; in this way the selective collection is facilitated, thus eliminating the negative impact on public health. 
The data collection used for the case study is limited due the use of purposeful sampling. That could affect the fidelity of the results. Still, in the next years we intend to extend the study to additional community initiatives in the waste management field. As well, the external validity is hard to be verified because, due to the limited number of research papers on this specific topic in Romania, we can hardly compare it with similar studies.

Effective strategies to promote public awareness of waste production prevention and to reduce the generation of specific types of waste are already operating in EU Member States and non-EU Countries. We can observe that there are significant differences in terms of municipal waste generated and in most of the EU countries the figures have a descending trend from 2007 to 2016. Furthermore, the recycling rate increased in most of the EU Member States. However, there is a very big gap among the EU countries regarding the recycling rate (from $66.1 \%$ to $7.1 \%$ ), as well as the EU average (45.8\% in 2016). In the EU, a lot of municipal waste is recycled (over 28\%) and incinerated (over 26\%). Romania is among the countries where more than $80 \%$ of the municipal waste reaches the landfill, while in the EU the average is $28.35 \%$. However, the share of the municipal waste that reaches the landfill decreased in Romania, from almost $100 \%$ to approximately $80 \%$ and the waste management system experiences improvements through the implementation of appropriate measures. Our correlative analysis revealed the fact that in the countries with a high environmental tax there is a high amount of material recycling in comparison to the countries where an environmental tax is low and only a low amount of waste is recycled. At the same time, in the countries with a small amount of environmental tax revenues, there is a significant rate of waste deposited to the landfill.

In Romania, the average amount of waste generated per capita is lower than the European average, but it seems that there is also a waste production not recorded in Romanian statistics. In Romania, waste management is experiencing difficulties in terms of collection, transport, treatment, recovery and disposal.

Moreover, all are closely related and if one element is missing in this chain, the process cannot work. The examples of community-based initiatives discussed in this paper supports the idea that only a close collaboration between authorities and initiatives can lead to achieving the targets set by the Romanian Government in the waste field, in respect to EU provisions.

The situation at a local level must be monitored, in order to identify where there is no sustainable plan for waste management. Ministry of Environment and its subordinated agencies must monitor the performance of local authorities regarding waste management, apply firm measures to discourage waste disposal in landfills or incineration and publish the ranking of municipalities in terms of waste management performance.

In order to move closer to a society that is not wasteful and manages waste in a sustainable manner, the following are necessary: good knowledge on waste policies in the EU, waste prevention policies that envisage a broad area of economic sectors, an overall eco-efficient recycling policy that covers all waste materials and collaboration with local government authorities to increase efficiency and quality of waste collected, making them easier to recycle and to capitalize. 
A close collaboration among national government, local authorities and communitybased initiatives in the field of waste management may represent a key strategic move. In the context of the UN-Habitat's (2010) report on “Solid Waste Management in the World's Cities", that reveals that there is no "one-size-fits-all" solution, our research concludes that only by involving all stakeholders in the design, adoption, and adaptation of appropriate strategies, a sustainable waste management system can be achieved to match the requirements of the European Union.

\section{Disclosure statement}

Authors declare they have no competing financial, professional, or personal interests from other parties.

\section{References}

Administraţia Fondului pentru Mediu. (2018). Retrieved from https://www.afm.ro

Agenția Națională pentru Protecția Mediului. (2018). Retrieved from http://www.anpm.ro

Albu, A. (2017) Industrial symbiosis: An innovative tool for promoting green growth. In W. Leal Filho, D. M. Pociovalisteanu, \& A. Q. Al-Amin (Eds.), Sustainable economic development - green economy and green growth (pp. 1-29). World Sustainability Series. Switzerland, Cham: Springer International Publishing. https://doi.org/10.1007/978-3-319-45081-0_1

Almași, A. M. (2013). Municipal waste management in Romania. European Environment Agency (EEA) under its 2012 work programme as a contribution to the EEA's work on waste implementation. Retrieved from www.eea.europa.eu/publications

Al-Salem, S. M., Lettieri, P., \& Baeyens, J. (2009). Recycling and recovery routes of plastic solid waste (PSW): A review. Waste Management, 29(10), 2625-2643.

https://doi.org/10.1016/j.wasman.2009.06.004

Bartelings, H., van Beukering, P., Kuik, O., Linderhof, V., \& Oosterhuis, F. (2005). Effectiveness of landfill taxation. The Netherlands, Amsterdam: Institute for Environmental Studies. Retrieved from http:// www.ivm.vu.nl/en/Images/Effective_landfill_R05-05_tcm53-102678_tcm234-103947.pdf

Becidan, M., Wang, L., Fossum, M., Midtbust, H. O., Stuen, J., Bakken, J. I., \& Evensen, E. (2015). Norwegian Waste-to-Energy (WtE) in 2030: Challenges and opportunities. Chemical Engineering Transactions, 43, 2401-2406. Retrieved from https://www.aidic.it/cet/15/43/401.pdf

Bolaane, B. (2006). Constraints to promoting people centred approaches in recycling. Habitat International, 30(4), 731-740. https://doi.org/10.1016/j.habitatint.2005.10.002

Burlakovs, J., Kriipsalu, M., Klavins, M., Bhatnagar, A., Vincevica-Gaile, Z., Stenis, J., Jani, Y., Mykhaylenko, V., Denafas, G., Turkadze, T., Hogland, M., Rudovica, V., Kaczala, F., Møller Rosendal, R., \& Hogland, W. (2017). Paradigms on landfill mining: from dump site scavenging to ecosystem services revitalization. Resources, Conservation and Recycling, 123, 73-84. https://doi.org/10.1016/j.resconrec.2016.07.007

Cahill, R., Grimes, S. M., \& Wilson, D. C. (2011). Review article: Extended producer responsibility for packaging wastes and WEEE - a comparison of implementation and the role of local authorities across Europe. Waste Management \& Research, 29(5), 455-479. https://doi.org/10.1177/0734242X10379455

Căilean Gavrilescu, D., \& Teodosiu, C. (2016). An assessment of the Romanian solid waste management system based on sustainable development indicators. Sustainable Production and Consumption, 8 , 45-56. https://doi.org/10.1016/j.spc.2016.07.004 
Care sunt obligatiile de mediu ale institutiilor publice? (2018). Retrieved from http://www.raportaremediu.ro/2018/05/30/obligatii-mediu-institutii-publice

Celata, F., \& Sanna, V. S. (2014). Community activism and sustainability: A multi-dimensional assessment (Working paper n. 137). Università degli Studi di Roma "La Sapienza". Facoltà di Economia. Dipartimento di Metodi e Modelli per l'Economia il Territorio e la Finanza MEMOTEF. Retrieved from https://core.ac.uk/download/pdf/33156149.pdf

Charuvichaipong, C., \& Sajor, E. (2006). Promoting waste separation for recycling and local governance in Thailand. Habitat International, 30(3), 579-594. https://doi.org/10.1016/j.habitatint.2005.02.002

Cobo, S., Dominguez-Ramos, A., \& Irabien, A. (2018). From linear to circular integrated waste management systems: A review of methodological approaches. Resources, Conservation and Recycling, 135, 279-295. https://doi.org/10.1016/j.resconrec.2017.08.003

Cucchiella, F., D’Adamo, I., \& Gastaldi, M. (2017). Sustainable waste management: Waste to energy plant as an alternative to landfill. Energy Conversion and Management, 131, 18-31.

https://doi.org/10.1016/j.enconman.2016.11.012

Cunha Marques, R., \& Ferreira DaCruz, N. (2016). Recycling and extended producers responsability: The European Experience. London: Routledge.

ETC/SCP \& European Environment Agency (EEA). (2013a). Municipal waste management in Romania. Prepared by A. M. Almasi ETC/SCP.

ETC/SCP \& European Environment Agency (EEA). (2013b). Municipal waste management in Norway. Prepared by Birgitte Kjær ETC/SCP.

European Commission. (2010a). Directorate-General for the environment. Being wise with waste: The EU's approach to waste management. Retrieved from http://ec.europa.eu/environment/waste/pdf/ WASTE\%20BROCHURE.pdf

European Commission. (2010b). Making sustainable consumption and production a reality. A guide for business and policy makers to Life Cycle Thinking and Assessment. Retrieved from http:// ec.europa.eu/environment/pubs/pdf/sustainable.pdf

European Commission. (2016). Study on the efficient functioning of waste markets in the EU (Final report July 2016). Retrieved from http://ec.europa.eu/environment/waste/studies/pdf/waste_market_study.pdf

European Commission. (2018a). Circular economy: New rules will make EU the global front-runner in waste management and recycling - Press release. Brussels, 22 May. Retrieved from http://europa.eu/ rapid/press-release_IP-18-3846_en.htm

European Commision. (2018b). Policies and Strategies - Waste - Environment. Retrieved from http:// ec.europa.eu/environment/waste/strategy.htm

European Environment Agency (EEA). (2009). Diverting waste from landfill. Effectiveness of waste management policies in the European Union. EEA Report, No. 7/2009. Luxembourg: Office for Official Publications of the European Communities. Retrieved from http://www.eea.europa.eu/publications/ diverting-waste-from-landfill-effectiveness-of-waste-management-policies-in-the-european-union

Eurostat. (2013). Retrieved from http://ec.europa.eu/eurostat

Eurostat. (2014). Retrieved from http://ec.europa.eu/eurostat

Eurostat. (2016). Retrieved from http://ec.europa.eu/eurostat

Eurostat. (2018). Retrieved from http://ec.europa.eu/eurostat

Evison, T., \& Read, A. D. (2001). Local Authority recycling and waste-awareness publicity/promotion. Resources, Conservation and Recycling, 32(3-4), 275-291.

https://doi.org/10.1016/S0921-3449(01)00066-0

Filho, W. L., Pociovalisteanu, D. M., \& Al-Amin, A. Q. (Eds.). (2017). Sustainable economic development, green economy and green growth. Switzerland: Springer International Publishing. 
Fischer, C., Lehner, M., \& McKinnon, D. (2012). Overview of the use of landfill taxes in Europe (ETC/ SCP working paper 1/2012). Retrieved from https://scp.eionet.europa.eu/publications/WP2012_1/ wp/WP2012_1

Gálvez-Martos, J. L., Styles, D., Schoenberger, H., \& Zeschmar-Lahl, B. (2018). Construction and demolition waste best management practice in Europe. Resources, Conservation and Recycling, 136, 166-178. https://doi.org/10.1016/j.resconrec.2018.04.016

Garda Naţională de Mediu. (2018). Retrieved from https://www.gnm.ro/about.php

Garlapati, V. K. (2016). E-waste in India and developed countries: Management, recycling, business and biotechnological initiatives. Renewable and Sustainable Energy Reviews, 54, 874-881. https://doi.org/10.1016/j.rser.2015.10.106

Gonçalves, D. S. (2014). Tecnologias de informação e comunicação para otimização da recolha de resíduos recicláveis (Master's thesis). Lisboa: ISCTE-IUL, Portugal.

Hotta, Y., \& Aoki-Suzuki, C. (2014). Waste reduction and recycling initiatives in Japanese cities: Lessons from Yokohama and Kamakura. Waste Management \& Research, 32(9), 857-866. https://doi.org/10.1177/0734242X14539721

Johansson, N., Krook, J., \& Eklund, M. (2012). Transforming dumps into gold mines. Experiences from Swedish case studies. Environmental Innovation and Societal Transitions, 5, 33-48. https://doi.org/10.1016/j.eist.2012.10.004

Joseph, K. (2006). Stakeholder participation for sustainable waste management. Habitat International, 30(4), 863-871. https://doi.org/10.1016/j.habitatint.2005.09.009

Karak, T., Bhagat, R. M., \& Bhattacharyya, P. (2012). Municipal solid waste generation, composition, and management: The World Scenario. Critical Reviews in Environmental Science and Technology, 42(15), 1509-1630. https://doi.org/10.1080/10643389.2011.569871

Kiddee, P., Naidu, B. R., \& Wong, M. H. (2013). Electronic waste management approaches: An overview. Waste Management, 33(5), 1237-1250. https://doi.org/10.1016/j.wasman.2013.01.006

Kurz, T., Linden, M., \& Sheehy, N. (2007). Attitudinal and community influences on participation in new curbside recycling initiatives in Northern Ireland. Environment and Behavior, 39(3), 367-391. https://doi.org/10.1177/0013916506294152

Lazarevic, D., Aoustin, E., Buclet, N., \& Brandt, N. (2010). Plastic waste management in the context of a European recycling society: Comparing results and uncertainties in a life cycle perspective. $R e-$ sources, Conservation and Recycling, 55(2), 246-259. https://doi.org/10.1016/j.resconrec.2010.09.014

McDonald, S., \& Oates, C. (2003). Reasons for non-participation in a Kerbside recycling scheme. Resources, Conservation, and Recycling, 39(4), 369-385. https://doi.org/10.1016/S0921-3449(03)00020-X

Ministerul Mediului. (2018). Retrieved from http://www.mmediu.ro/categorie/minister/6

Nuortio, T., Kytojoki, J., Niska, H., \& Braysy, O. (2006). Improved route planning and scheduling of waste collection and transport. Expert Systems with Applications, 30(2), 223-232. https://doi.org/10.1016/j.eswa.2005.07.009

OECD. (2013). Waste management services, October 2013. Retrieved from http://www.oecd.org/daf/ competition/Waste-management-services-2013.pdf

Planul Naţional de Gestionare a Deșeurilor (Monitorul Oficial al României, Partea 1, Nr. 11 bis / 5.01.2018). (2018). Bucharest. Retrieved from http://www.mmediu.ro/app/webroot/uploads/ files/2018-01-10_MO_11_bis.pdf

Popescu, V., \& Pintilie, V. (2013). Detailed characterisation of future waste management Projects (20142020) - Romania - JASPERS.

Ramos, T. R. P., Morais, C. S., \& Barbosa-Póvoa, A. P. (2018). The smart waste collection routing problem: Alternative operational management approaches. Expert Systems with Applications, 103, 146-158. https://doi.org/10.1016/j.eswa.2018.03.001 
Report from the Nordic Competition Authorities. Competition in the waste management sector - Preparing for a circular economy (2016). Retrieved from http://www.konkurrensverket.se/globalassets/ publikationer/nordiska/nordic-report-2016_waste-management-sector.pdf

Robbins, C., \& Rowe, J. (2002). Unresolved responsibilities: exploring local democratisation and sustainable development through a community-based waste reduction initiative. Local Government Studies, 28(1), 37-58. https://doi.org/10.1080/714004128

România în cifre. Breviar Statistic 2017. (2017). Bucharest: Institutul Naţional de Statistică. Retrieved from http://www.insse.ro/cms/sites/default/files/field/publicatii/romania_in_cifre_2017_0.pdf

Scorțar, L. M., Lazăr, I., \& Zagan Zelter, D. (2009). The condition of waste management in Romania. Manage Marketing Journal, 7(1), 29-35. Retrieved from http://www.mnmk.ro/documents/2009/3 Scortar_FFF.pdf

Sthiannopkao, S., \& Wong, M. H. (2013). Handling e-waste in developed and developing countries: Initiatives, practices, and consequences. Science of the Total Environment, 463-464, 1147-1153. https://doi.org/10.1016/j.scitotenv.2012.06.088

Subash, A. (2006). Community participation in solid waste management. Office of Environmental Justice.

Taelman, S. E., Tonini, D., Wandl, A., \& Dewulf, J. (2018). A holistic sustainability framework for waste management in European Cities: Concept development. Sustainability, 10(7), 2184. https://doi.org/10.3390/su10072184

Tambovceva, T., \& Geipele, I. (2012). Environmental management systems experience among Latvian construction companies. Technological and Economic Development of Economy, 17(4), 595-610. https://doi.org/10.3846/20294913.2011.603179

Tanskanen, P. (2013). Management and recycling of electronic waste. Acta Materialia, 61(3), 1001-1011. https://doi.org/10.1016/j.actamat.2012.11.005

Târțiu, V. (2011). Selective collection of municipal waste in Romania: Characteristics and challenges. Management Research and Practice, 3(3), 53-62. Retrieved from http://mrp.ase.ro/no33/f6.pdf

The Government of Romania. (2004). Government Decision no. 1470/2004 on the approval of the national waste management strategy and the waste management national plan. Published in the Official Monitor no. 954 from 18 October 2004. Romania. Retrieved from http://www.mmediu.ro/beta/ wp-content/uploads/2012/05/2012-05-17_hg_1470_2004.pdf

The Government of Romania. (2005). Government Decision no. 349/2005 on the storage of waste. (2005). Published in the Official Monitor no. 394 from 10 May 2005. Romania. Retrieved from www.anpm. ro/anpm_resources/migrated_content/uploads/3767_HG\%20349_2005.doc

The Government of Romania. (2005). Government Decision no. 621/2005. Published in the Official Monitor no. 639 from 20 July 2005. Romania. Retrieved from http://www.mmediu.ro/beta/wpcontent/uploads/2012/05/2012-05-18_hg_621_2005.pdf

The Government of Romania. (2005). Government Emergency Ordinance no. 196/2005 on the Environmental Fund. Published in the Official Monitor no. 1193 from 30 December 2005. Romania. Retrieved from https://www.afm.ro/main/legislatie_taxe_si_contributii/2017/oug_196_2005_17072017.pdf

The Government of Romania. (2010). Government Decision no. Regulation 1037/2010. Published in the Official Monitor no. 728 from 2 November 2010. Romania. Retrieved from http://www.mmediu.ro/ beta/wp-content/uploads/2012/05/2012-05-18_hg_1037_2010.pdf

The Government of Romania. (2018). Government Emergency Ordinance no. 74/2018. Published in the Official Monitor no. 630 from 19 July 2018. Romania. Retrieved from http://www.asrm.ro/ pdf/noutati/noutati-legislative-iulie-2018/OU_74-2018_MODIFICA_LEGE_DEESURI,_AMBALAJE,_AFM.pdf

The Romanian Parliament (2011). Law no. 211/2011 on the waste regime. Published in the Official Monitor no. 837 from 25 November 2011 Romania. Retrieved from http://www.mmediu.ro/beta/ wp-content/uploads/2012/05/2012-05-17_LEGE_211_2011.pdf 
UN-HABITAT. (2010). Solid waste management in the world's cities. Water and sanitation in the world's cities report 2010. Washington DC: Earthscan. https://doi.org/10.4324/9781849774871

Vicente, P., \& Reis, E. (2008). Factors influencing households' participation in recycling. Waste Management \& Research, 26, 140-146. https://doi.org/10.1177/0734242X07077371

Wilson, C. D. H., \& Williams, I. D. (2007). Kerbside collection: a case study from the north-west of England. Resources, Conservation and Recycling, 52(2), 381-394. https://doi.org/10.1016/j.resconrec.2007.02.006

Wilson, D. C., Velis, C., \& Cheeseman, C. (2006). Role of informal sector recycling in waste management in developing countries. Habitat International, 30(4), 797-808. https://doi.org/10.1016/j.habitatint.2005.09.005

Zaman, A. U. (2014). Measuring waste management performance using the "Zero Waste Index": The case of Adelaide, Australia. Journal of Cleaner Production, 66, 407-419. https://doi.org/10.1016/j.jclepro.2013.10.032

Zaman, A. U. (2015). A comprehensive review of the development of zero waste management: Lessons learned and guidelines. Journal of Cleaner Production, 91, 12-25. https://doi.org/10.1016/j.jclepro.2014.12.013

Zorpas, A. A., Lasaridi, K., Pociovălişteanu, D. M., \& Loizia, P. (2018). Monitoring and evaluation of prevention activities regarding household organics waste from insular communities. Journal of Cleaner Production, 172, 3567-3577. https://doi.org/10.1016/j.jclepro.2017.03.155 